\title{
Two-year Quaternary Isolation of Gram-positive Bacilli Using MALDI-TOF MS in Positive Blood Culture of a University Hospital
}

\author{
Jin-Un Choi ${ }^{1}$, Young-Bin $\mathrm{Yu}^{2}$, Sang-Ha Kim ${ }^{3}$, Seungho Won ${ }^{4}$, Young-Kwon Kim ${ }^{2}$ \\ ${ }^{1}$ Department of Laboratory Medicine, Chonnam National University Hospital, Gwangju, Korea \\ ${ }^{2}$ Department of Biomedical Laboratory Science, College of Medical Sciences, Konyang University, Daejeon, Korea \\ ${ }^{3}$ Department of Laboratory Medicine, Konyang University Hospital, Daejeon, Korea \\ ${ }^{4}$ Department of Mechanical Engineering, Konyang University, Nonsan, Korea
}

\section{일개 대학병원의 혈액배양에서 MALDI-TOF MS를 이용한 Gram-positive Bacilli의 2년간 분기별 분리율}

\author{
최진언 ${ }^{1}$, 유영빈 ${ }^{2}$, 김상하 ${ }^{3}$, 원승호 ${ }^{4}$, 김영권 $^{2}$ \\ ${ }^{1}$ 전남대학교병원 진단검사의학과, ${ }^{2}$ 건양대학교 의과학대학 임상병리학과, ${ }^{3}$ 건양대학교병원 진단검사의학과, ${ }^{4}$ 건양대학교 기계공학과
}

\begin{abstract}
In this study, Gram-positive bacilli (GPB) were identified by MALDI-TOF MS and analyzed according to the quaternary and microbial strains in the blood culture medium over a two year period at a university hospital. The results were as follows. The overall positive rate of blood culture was $9.97 \%$. In 713 isolated GPB, 410 strains (57.5\%) were identified using a microflex MALDI Biotyper. The positive rate of GPB among the blood culture positive bacteria was $8.2 \%$, and the quarterly isolation rate was $9.8 \%$ in the third quarter of $2015,8.7 \%$ in the second quarter of 2016 , $8.1 \%$ in the third quarter of $2016,8.1 \%$ in the first quarter of $2015,7.9 \%$ in the first quarter of $2015,7.9 \%$ in the second quarter of $2015,6.8 \%$ in the first quarter of 2016 , and $6.7 \%$ in the fourth quarter of 2015. The isolates were Corynebacterium striatum 89 (12.4\%), Bacillus cereus 60 (8.4\%), Bacillus subtilis 30 (4.2\%), Paenibacillus urinalis 29 (4.1\%), and Listeria monocytogenes $25(3.5 \%)$. The results of $16 \mathrm{~S}$ rRNA sequencing of 43 isolates (86.0\%) were consistent with those of the other 50 isolates. Five out of the seven unmatched weeks were not identified by MALDI-TOF MS.
\end{abstract}

Key words: Blood culture, Gram positive bacilli, Isolation rate, MALDI-TOF MS

This is an Open Access article distributed under the terms of the Creative Commons Attribution Non-Commercial Licens (http://creativecommons.org/licenses/by-nc/4.0) which permits unrestricted non-commercial use, distribution, and reproduction in any medium, provided the original work is properly cited.

Copyright (c) 2018 The Korean Society for Clinical Laboratory Science. All rights reserved.
Corresponding author: Young-Kwon Kim Department of Biomedical Laboratory Science, College of Medical Sciences, Konyang University, 158 Gwanjeodong-ro, Seo-gu, Daejeon 35365, Korea Tel: 82-42-600-8431 Fax: 82-42-543-6370

E-mail: ykkim3245@konyang.ac.kr

Received: August 18, 2018 Revised: September 4, 2018 Accepted: September 9, 2018

\section{서 론}

임상미생물검사실에서 분리되는 그람양성 막대균(Grampositive bacilli, GPB)의 대부분은 환경에 존재하며 비병원성 으로 알려져 있어, 그 동안 임상미생물 검사실에서는 오염균으 로 간주하여 정확한 동정을 시행하지 않는 것이 일반적이었다
[1]. 그러나 GPB 중 몇몇 병원성 균종들은 임상적으로 중요하 며, 최근 면역저하 환자나 체내 삽입기구 처치를 하는 환자가 증 가하고 항생제 사용도 증가함에 따라 GPB에 의한 기회감염이 증가하고 있다. 따라서 $\mathrm{GPB}$ 의 신속하고 정확한 동정의 필요성 이 대두되었고, 정확한 $\mathrm{GPB}$ 의 동정은 감염의 정확한 진단과 적 절한 치료에 큰 도움을 주기 때문에 매우 중요하다고 볼 수 있다 
[2]. 일반적으로 혈액배양에서 분리되는 GPB들은 비용의 효율 적인 측면에서 동일 환자에서 2 회 이상 분리되는 경우에만 감염 의 의미를 가지고 동정을 시행하지만, 임상미생물 검사실에서 시행하고 있는 전통적인 동정방법으로는 동정 시간이 많이 걸 리고 항상 정확한 결과를 얻기가 어렵다[3]. 특히 패혈증의 경우 는 미생물에 감염되어 일어나는 전신성 반응으로 사망률 또한 높은 질환이며 경제적 부담을 증가시킨다[4]. 중환자실 환자의 경우 패혈증으로 인한 중증 패혈증으로 20 50\%의 사망률을 나타내며, 패혈성 쇼크 환자는 다른 질환에 비해 사망률이 각각 $30 \sim 87 \%$ 에 이를 정도로 심각한 질환으로 많은 경제적 부담을 증가시키므로 패혈증의 원인균을 신속하게 진단하고 치료의 방 향을 신속하게 제시해 줌으로써 환자의 예후에 큰 영향을 미칠 수 있다[5]. 따라서 임상 미생물 검사실에서는 저렴한 비용으로 좀 더 신속하게 원인균을 동정해 내고자 노력하고 있다. 그러나 일반적으로 행해지고 있는 생화학적 동정방법으로는 최소 2일 최대 4일 정도의 시간이 소요된다[6]. 최근 개발된 microflex MALDI Biotyper (Bruker Daltonik GmbH, Bremen, Germany)는 MALDI-TOF MS 기법을 이용하여 얻은 세균의 단백질 정보를 이미 구축된 각 균종에 대한 정보와 비교 분석하 여 균종을 동정하는 원리를 이용한다. Seng 등[6]의 연구에 의 하면 MALDI-TOF MS 동정 시간은 균주 당 평균 6분 정도 소요 되며, 동정을 위해 산출되는 비용은 상품화 키트를 포함한 전통 적 동정방법의 22 32\%로 임상 미생물 검사실에서 이용하기 에 간편하고 동정에 소요되는 것으로 보고하였다[7, 8]. 혈액배 양 시료에서 직접 세균 동정과 항생제 감수성 시험실시하는 방 법은 정확하고 결과를 보고하는데 까지 소요 되는 시간을 크게 감소시켜 효율적인 치료에 유용하게 활용될 수 있다[9]. 대부분 의 MALDI-TOF MS 장비를 이용한 연구에서는 임상미생물 검 사실에서 주로 동정이 되는 그람양성 알균, 그람음성 막대균 및 매우 소수의 GPB을 포함하여 동정하고 있다[10, 11]. 그러나 국 내에서는 MALDI-TOF MS를 이용한 혈액배양에서 GPB분리 동정률에 대한 자료가 부족하여, 본 연구에서는 일개 대학병원 의 혈액배양에서 분리된 전체 세균을 대상으로 MALDI-TOF $\mathrm{MS}$ 를 이용하여 $\mathrm{GPB}$ 의 균종별, 분기별 분리 비율을 조사하여 혈액배양에서 전통적 방법으로 동정되지 못하거나 오염균으로 간과 할 수 있는 오류를 최소화 하기 위한 기초자료를 알아보고 자 하였다.

\section{재료 및 방법}

2014년 10월부터 2016년 9월까지 2년간 일개 대학병원 임
상미생물 검사실로 혈액 배양이 의뢰된 87,241 건 중에서 $\mathrm{GPB}$ 로 분리된 713균주를 대상으로 하였으며, 분기별 혈액배양 양 성률 중 $\mathrm{GPB}$ 의 분리율을 분석하였다.

\section{1. 혈액 배양}

혈액배양은 산소성 배지인(BacT/ALERT FA Plus, FA)와 BACTEC ${ }^{\mathrm{TM}}$ Plus Anerobic/F), 무산소성 배지인(BacT/ALERT Standard Anaerobic, $\mathrm{SN}$ )와 (BACTEC ${ }^{\mathrm{TM}}$ Plus Anerobic/F)에 각각 $5 \mathrm{~mL}$ 씩 접종하였으며, 각각 BacT/ALERT 3D blood culture system (bioMérieux Inc., Durham, NC, USA)과 BD BACTEC $^{\mathrm{TM}}$ FX blood culture system (BD, Spark, MD)에서 5 일간 배양하였다. 혈액배양 양성 배양액을 5\% sheep blood agar plate (Hanil Komed)에 접종하여 $5 \% \mathrm{CO}_{2}, 35^{\circ} \mathrm{C}$ 배양기에 서 24 시간에서 48 시간 동안 배양하였다. 분리된 균종들은 집락 성상과 그람염색 결과를 이용하여 $\mathrm{GPB}$ 로 일차 분류하였다.

\section{MALDI-TOF MS를 이용한 동정}

전통적 혈액배양에서 양성인 배양액을 혈액우무배지에 배양 한 후 집락 성상과 그람염색 결과 $\mathrm{GPB}$ 로 확인된 균주를 대상으 로 microflex MALDI Biotyper (Bruker Daltonik GmbH, Bremen, Germany)로 검사하고 MALDI Biotyper RTC software (V. 3.1)을 이용하여 직접 도말법으로 균종을 동정하 였다. 직접 도말법은 하룻밤 배양한 신선한 집락을 멸균 Wooden applicator 를 이용해 MSP 96 target polished steel BC microscout Target plate (Bruker Daltonics)에 도말하고, 세균이 마른 후 매트릭스 용액(50\% acetonitrile, 2.5\% trifluoroacetic acid)에 포화된( $\alpha$-cyano-4-hydroxycinnamic $\mathrm{acid})$ 을 더한 시약 $1 \mu \mathrm{L}$ 를 가하고, 실온에서 완전히 건조시킨 후 microflex MALDI Biotyper 장비에 장착하였다. Bacterial test standard (BTS)를 사용하여 장비 Calibration을 실시하였고, $\mathrm{m} / \mathrm{z} 2,000$ 20,000 범위에서 측정된 Mass spectra 동정 결과 는 MALDI Bio- typer RTC software (V. 3.1)를 이용해 분석하 였다. 동정은 기기 회사의 기준을 이용하여 판정하였는데, 일반 적으로 동정치(cut-off score)가 2.0 이상이면 균종 동정이, 1.7 이상이면서 2.0 미만인 경우 균속 동정이 가능한 것으로 판단하 였고 1.7 미만인 경우 신뢰성이 없는 것으로 조작적 정의를 하였다.

\section{결 과}

\section{1. 혈액배양 분기별 분리 양성률 분석 1}

2014년 10월부터 2016년 9월까지 2년간 혈액배양에서 의 
뢰 건수 총 87,241 건 중 전체 양성은 8,699건으로 9.97\%를 나 타내었고, 그 중 Gram positive cocci는 4,198건(48.3\%), Gram negative bacilli 3,245건(37.3\%), GPB 713건(8.2\%), Candida species는 513건(5.9\%), Gram negative cocci 30건 (0.3\%) 순으로 분리되었다. 2014 년 4 분기 의뢰 건수 총 10,168 건 중 전체 양성률은 1,028 건으로 $10.1 \%$ 를 나타내었고, 그 중 Gram positive cocci는 562건(54.7\%), Gram negative bacilli 343건(33.4\%), GPB 83건(8.1\%), Candida species 38건 (3.7\%), Gram negative cocci 2건(0.2\%)를 나타냈으며, 2015 년 1 분기는 의뢰 건수 총 9,732 건 중 전체 양성률은 861 건으로 $8.8 \%$ 를 나타내었고, 그 중 Gram positive cocci 457건 (55.2\%), Gram negative bacilli 266건(30.9\%), GPB 68건 (7.9\%), Candida species 46건(5.3\%), Gram negative cocci 6 건(0.7)\%를 나타냈으며, 2015년 2분기 총 9,574건 중 양성은 998건(10.4\%)을 나타내었고, 그 중 Gram positive cocci 517 건(51.8\%), Gram negative bacilli 339건(34.1\%), GPB 83건 (7.9\%), Candida species 52건(5.2\%), Gram negative cocci 7 건(0.7\%)를 나타냈다. 2015년 3분기 총 의뢰 건수 11,255 건 중 양성은 1,263 건으로 $1.2 \%$ 를 나타냈으며, 그 중 Gram positive cocci 572건(45.3\%), Gram negative bacilli 481건(38.1\%), GPB 124건(9.8\%), Candida species 81건(6.4\%), Gram negative cocci 5건(0.4\%)를 나타냈다. 2015년 4분기 총 11,163 건 중 양성은 1139 건(10.2\%)이었으며, 그 중 Gram positive cocci 508건(44.6\%), Gram negative bacilli 412건 (36.2\%), Candida species 131건(11.5\%), GPB 84건(6.7\%), Gram negative cocci 4건(004\%)의 순으로 나타났다. 2016년 1 분기는 총 11,321 건중 양성은 950 건(8.4\%)이었으며, 그 중 Gram positive cocci 415건(43.7\%), Gram negative bacilli
409건(43.1\%), GPB 65건(6.8\%), Candida species 57건 (6.6\%), Gram negative cocci 4건(0.4\%)을 나타냈다. 2016년 2 분기 총 의뢰 건수 11,937 건 중 양성은 1212 건(10.2\%)이었으 며, 그 중 Gram positive cocci 537건(43.3\%), Gram negative bacilli 507건(41.8\%), GPB 105건(8.1\%), Candida species 62 건(5.1\%), Gram negative cocci 1건(0.01\%)로 나타났으며, 2016년 3분기 총 의뢰 건 수 12,091 건 중 양성은 1,248 주 (10.3\%)이었으며, 그 중 Gram positive cocci 612건(49.0\%), Gram negative bacilli 488건(39.1\%), GPB 101건(8.1\%), Candida species 46건(3.7\%), Gram negative cocci 1건 (0.01\%) 순으로 분리되었다. 총 혈액배양 양성률은 $10.0 \%$ 였으 며 양성세균 중 $\mathrm{GPB}$ 양성률은 8.2\%였다(Table 1, Figure 1).

\section{MALDI-TOF를 이용한 그람 양성 막대균의 분리율}

총 713건의 GPB를 microflex MALDI Biotyper를 이용해 동정하여 기기 회사의 기준에 따라 균속 동정이 가능한 스코어

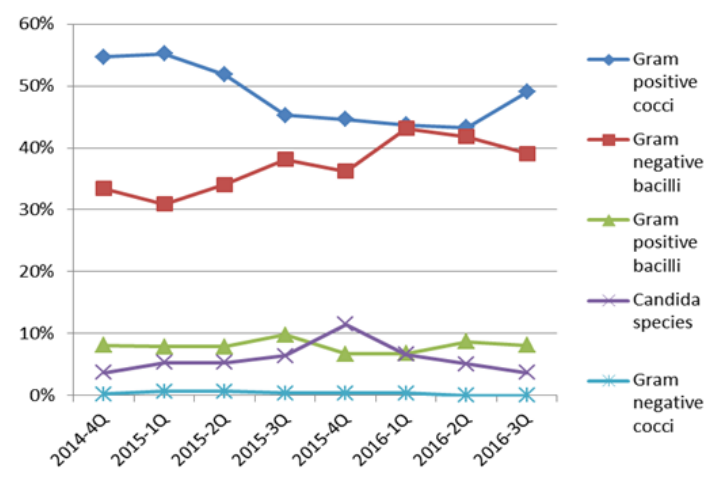

Figure 1. Quarterly in year positive blood cultures at one university hospital (2014 2016).

Table 1. Quarterly in year positive blood cultures at one university hospital (2014 2016)

\begin{tabular}{lcccccc}
\hline & \multicolumn{5}{c}{ No. (\%) of results obtained from blood culture } \\
\cline { 2 - 7 } Quarter in year & $\begin{array}{c}\text { Gram } \\
\text { positive bacilli }\end{array}$ & $\begin{array}{c}\text { Gram } \\
\text { positive cocci }\end{array}$ & $\begin{array}{c}\text { Gram } \\
\text { negative bacilli }\end{array}$ & $\begin{array}{c}\text { Gram } \\
\text { negative cocci }\end{array}$ & $\begin{array}{c}\text { Candida } \\
\text { species }\end{array}$ & Positivity (\%) \\
\hline 2014-4Q* & $83(8.1)$ & $562(54.7)$ & $343(33.4)$ & $2(0.2)$ & $38(3.7)$ & $1028 / 10168(10.1)$ \\
$2015-1 Q$ & $68(7.9)$ & $475(55.2)$ & $266(30.9)$ & $6(0.7)$ & $46(5.3)$ & $861 / 9732(8.8)$ \\
$2015-2 Q$ & $83(7.9)$ & $517(51.8)$ & $339(34.1)$ & $7(0.7)$ & $52(5.2)$ & $998 / 9574(10.4)$ \\
$2015-3 Q$ & $124(9.8)$ & $572(45.3)$ & $481(38.1)$ & $5(0.4)$ & $81(6.4)$ & $1263 / 11255(11.2)$ \\
$2015-4 Q$ & $84(6.7)$ & $508(44.6)$ & $412(36.2)$ & $4(0.4)$ & $131(11.5)$ & $1139 / 11163(10.2)$ \\
$2016-1 Q$ & $65(6.8)$ & $415(43.7)$ & $409(43.1)$ & $4(0.4)$ & $57(6.6)$ & $950 / 11321(8.4)$ \\
$2016-2 Q$ & $105(8.7)$ & $537(43.3)$ & $507(41.8)$ & $1(0.01)$ & $62(5.1)$ & $1212 / 11937(10.2)$ \\
$2016-3 Q$ & $101(8.1)$ & $612(49.0)$ & $488(39.1)$ & $1(0.01)$ & $46(3.7)$ & $1248 / 12091(10.3)$ \\
Total & $713(8.2)$ & $4198(48.3)$ & $3245(37.3)$ & $30(0.3)$ & $513(5.9)$ & $8699 / 87241(100 / 9.97)$ \\
\hline
\end{tabular}

Abbreviations: No, number; Q, quarter.

1st quarter: Jan to Mar, 2nd quarter: Apr to Jun, 3rd quarter: Jul to Sep, 4th quarter: Oct to Dec. 
1.7 이상 균주는 410 주 $57.5 \%$ 였다. 동정은 되었으나 스코어 1.7 아래로 신뢰할 수 없는 결과를 보였던 균주는 213 주 $29.9 \%$ 였고 no peaks found로 동정이 안되는 균주는 90주 $12.6 \%$ 였 다. 스코어 1.7 이상에서 동정된 균주별 분리는 Corynebacterium striatum 89건(12.4\%), Bacillus cereus 60건(8.4\%), Bacillus subtilis 30건(4.2\%), Paenibacillus urinalis 29건(4.1\%), Listeria monocytogenes 25건(3.5\%), Clostridium perfringens 18건(2.5\%), Bacillus licheniformis 16건(2.2\%), Bacillus pumilus 12건(1.7\%)이었으며, Bacillus mojavensis, Corynebacterium afermentans, Bacillus sonorensis 각각 10건 (1.4\%)이었고, Microbacterium spp. 8건(1.1\%), Bacillus megaterium 7건(1.0\%)순으로 나타났다(Table 2).

\section{3. $16 \mathrm{~S}-\mathrm{rRNA}$ sequencing분석과 MALDI-TOF 동정 결과}

염기서열 분석을 위한 $\mathrm{PCR}$ 을 수행하기 위해 Forward primer인 16S-rRNA1 (5'-AGT TTG ATC CTG GCT CAG-3') 와 Reverse primer인 16S-rRNA2 (5'-GGT TAC CTT GTT ACG ACT T-3')를 이용하였다. Primer 각각 $20 \mathrm{pmol} 1 \mu \mathrm{L}$, dNTPs $1 \mu \mathrm{L}, 10 \mathrm{x}$ Reaction buffer (1x: $10 \mathrm{mM}$ Tris-HCL, 1.5 mM KCL, 0.1\% Triton X-100) $5 \mu \mathrm{L}, 2.5 \mathrm{U} / \mu \mathrm{L}$ DyNAzymeTM polymerase $1 \mu \mathrm{L}$, 멸균 DW $38.5 \mu \mathrm{L}$ 에 추출 된 gDNA $2.5 \mu \mathrm{L}$ 를 넣어 총 $50 \mu \mathrm{L}$ 로 반응액을 만들었다. $\mathrm{PCR}$ 은 TaKaRa PCR

Table 2. Identification of Gram positive bacilli by MALDI-TOF from blood culture (2014 2016)

\begin{tabular}{|c|c|c|c|c|c|c|c|c|c|c|}
\hline \multirow{2}{*}{$\begin{array}{c}\text { ID result by MALDI-TOF } \\
\text { Species }^{\mathrm{a}}\end{array}$} & \multicolumn{8}{|c|}{$\begin{array}{l}\text { No. of isolates with the number of } \\
\text { positive blood cultures per patient }\end{array}$} & \multirow{2}{*}{$\begin{array}{c}\text { Total No. (\%) } \\
\text { of patient }\end{array}$} & \multirow{2}{*}{$\begin{array}{c}\text { Total No. (\%) } \\
\text { of species }\end{array}$} \\
\hline & 1 & 2 & 3 & 4 & 5 & 6 & 8 & 11 & & \\
\hline Corynebacterium striatum & 17 & 9 & 2 & 3 & 1 & 2 & 1 & 1 & $36(5.9)$ & $89(12.4)$ \\
\hline Bacillus cereus & 47 & 5 & 1 & 0 & 0 & 0 & 0 & 0 & $53(8.6)$ & $60(8.4)$ \\
\hline Bacillus subtilis & 30 & 0 & 0 & 0 & 0 & 0 & 0 & 0 & $30(4.9)$ & $30(4.2)$ \\
\hline Paenibacillus urinalis & 27 & 1 & 0 & 0 & 0 & 0 & 0 & 0 & $28(4.6)$ & $29(4.1)$ \\
\hline Listeria monocytogenes & 3 & 7 & 0 & 2 & 0 & 0 & 0 & 0 & $12(2.0)$ & $25(3.5)$ \\
\hline Clostridium perfringens & 8 & 5 & 0 & 0 & 0 & 0 & 0 & 0 & $13(2.1)$ & $18(2.5)$ \\
\hline Bacillus licheniformis & 16 & 0 & 0 & 0 & 0 & 0 & 0 & 0 & $16(2.6)$ & $16(2.2)$ \\
\hline Bacillus pumilus & 12 & 0 & 0 & 0 & 0 & 0 & 0 & 0 & $12(2.0)$ & $12(1.7)$ \\
\hline Bacillus mojavensis & 10 & 0 & 0 & 0 & 0 & 0 & 0 & 0 & $10(1.6)$ & $10(1.4)$ \\
\hline Corynebacterium afermentans & 10 & 0 & 0 & 0 & 0 & 0 & 0 & 0 & $10(1.6)$ & $10(1.4)$ \\
\hline Bacillus sonorensis & 10 & 0 & 0 & 0 & 0 & 0 & 0 & 0 & $10(1.6)$ & $10(1.4)$ \\
\hline Microbacterium species & 3 & 0 & 0 & 0 & 1 & 0 & 0 & 0 & $4(0.7)$ & $8(1.1)$ \\
\hline Bacillus megaterium & 7 & 0 & 0 & 0 & 0 & 0 & 0 & 0 & $7(1.1)$ & $7(1.0)$ \\
\hline Mycobacterium abscessus & 0 & 0 & 0 & 0 & 0 & 1 & 0 & 0 & $1(0.2)$ & $6(0.8)$ \\
\hline Clostridium tertium & 6 & 0 & 0 & 0 & 0 & 0 & 0 & 0 & $6(1.0)$ & $6(0.8)$ \\
\hline Actinomyces oris & 5 & 0 & 0 & 0 & 0 & 0 & 0 & 0 & $5(0.8)$ & $5(0.7)$ \\
\hline Bacillus vallismortis & 5 & 0 & 0 & 0 & 0 & 0 & 0 & 0 & $5(0.8)$ & $5(0.7)$ \\
\hline Eggerthella lenta & 5 & 0 & 0 & 0 & 0 & 0 & 0 & 0 & $5(0.8)$ & $5(0.7)$ \\
\hline Bacillus infantis & 4 & 0 & 0 & 0 & 0 & 0 & 0 & 0 & $4(0.7)$ & $4(0.6)$ \\
\hline Clostridium carnis & 0 & 0 & 0 & 1 & 0 & 0 & 0 & 0 & $1(0.2)$ & $4(0.6)$ \\
\hline Actinomyces odontolyticus & 3 & 0 & 0 & 0 & 0 & 0 & 0 & 0 & $3(0.5)$ & $3(0.4)$ \\
\hline Bacillus mycoisea & 3 & 0 & 0 & 0 & 0 & 0 & 0 & 0 & $3(0.5)$ & $3(0.4)$ \\
\hline Bacillus thuringiensis & 2 & 0 & 0 & 0 & 0 & 0 & 0 & 0 & $2(0.3)$ & $2(0.3)$ \\
\hline Brevibacterium iodium & 0 & 1 & 0 & 0 & 0 & 0 & 0 & 0 & $1(0.2)$ & $2(0.3)$ \\
\hline Corynebacterium minutissimun & 2 & 0 & 0 & 0 & 0 & 0 & 0 & 0 & $2(0.3)$ & $2(0.3)$ \\
\hline Corynebacterium urealyticum & 0 & 1 & 0 & 0 & 0 & 0 & 0 & 0 & $1(0.2)$ & $2(0.3)$ \\
\hline Lactibacillus paracase ${ }^{b}$ & 10 & 0 & 0 & 0 & 0 & 0 & 0 & 0 & $10(1.6)$ & $10(1.4)$ \\
\hline Arthrobacter oxydans ${ }^{c}$ & 27 & 0 & 0 & 0 & 0 & 0 & 0 & 0 & $27(4.4)$ & $27(3.8)$ \\
\hline Not reliable identification & 205 & 4 & 0 & 0 & 0 & 0 & 0 & 0 & $209(34.0)$ & $213(29.9)$ \\
\hline No peaks found & 88 & 1 & 0 & 0 & 0 & 0 & 0 & 0 & $89(14.5)$ & $90(12.6)$ \\
\hline Total & 565 & 34 & 3 & 6 & 2 & 3 & 1 & 1 & $615(100.0)$ & $713(100.0)$ \\
\hline
\end{tabular}

${ }^{\mathrm{a}} \mathrm{D}$ result cut-off criteria: score $\geq 1.7 .{ }^{\mathrm{b}}$ Microbacterium aurum, Lysinibacillus fusiformis, Solibacillus silvestis, Paenibacillus illinoisensis. 'Bacillus atrophaeus, Bacillus circulans, Bacillus flexus, Bacillus muralis, Bacillus niacini, Bacillus thermoamylovorans, Bacillus weienstephanensis, Clostridium bifermentans, Clostridium innocuum, Corynebacterium amycolatum, Corynebacterium falsenii, Corynebacterium pseudodiphthriticum, Corynebacterium singulare, Corynebacterium tuscaniense, Dermabacter hominis, Exigubacterium aurantiacum, Gordona rubropertincta, Lactobaillus salivarius, Microbacterium oxydans, Microbacterium testaceum, Paenibacillus barengoltzii, Paenibacillus latus, Paenibacillus rhizosphaerae, Paenibacillus odorifer, Paenibacillus pauli, Paenibaillus xylanilyticus. 
Thermal cycler (TP600 Gradient, Roche Molecular System, $\mathrm{CA}, \mathrm{USA}$ )를 사용하였고, 온도 조건을 $94^{\circ} \mathrm{C}$ 에서 5 분 predenaturation시킨 후, $94^{\circ} \mathrm{C}$ 에서 1 분 dena- turation, $49^{\circ} \mathrm{C}$ 에 서 1분 annealing, $72^{\circ} \mathrm{C}$ 에서 1 분 extension을 1 주기로 36 회 실시하여 증폭하고 $72^{\circ} \mathrm{C}$ 에서 10 분간 postextension 을 실시 하였다. microflex MALDI Biotyper의 동정 결과와 생화학적 동정 결과와 일치하지 않는 총 50 주 중 43 주는 $16 \mathrm{~S}-\mathrm{rRNA}$ sequencing 분석 결과와 일치하였으나 7주는 일치하지 않았 다. 일치된 균주들은 Corynebacterium striatum 19주, Clostridium perfringens 5주, Listeria monocytogenes 9주, Bacillus iodinum 1주, Clostridium canis 1주, Corynebacterium urealyticum 1주, Mycobacteriumabscessus 1주, Paenibacillus urinalis 1 주 이었다. 1.7 이상의 스코어에서 동정되었던 균주 중 Bacillus cereus는 Lysinbacillus spp.로 Microbacterium spp.는 Mycobacterium paraoxydans로 각각 16S-rRNA sequencing 결과와 불일치하였고, 5 주는 MALDI-TOF MS에 서도 not reliable identification 혹은 no peaks found를 나타 내 동정해내지 못했던 균주들에 대한 16S-rRNA sequencing 분석 결과 Cellulomonas hominis, Corynebacteriumamycdatum, Catabacter hongkongenesis, Bacillus spp., Bacillus velezensis로 동정되었다(Table 3).

\section{고 찰}

혈액배양 양성은 세균성 균혈증을 나타낼 수 있는 것으로 생
각할 수 있지만 일부는 오염에 의한 혈액배양 양성이 존재할 수 있기 때문에 모두가 진정한 감염을 나타내지 않는다. 혈액배양 에서 분리되는 많은 $\mathrm{GPB}$ 의 대부분은 정상적인 피부 정상상재 균의 일부로 혈액배양을 오염 시키거나 정맥내 카테터에 집락 화 될 수 있다[2].

혈액배양에서 오염의 주된 원인균으로는 Propionibacterium acnes, Corynebacterium spp. 및 Bacillus spp.가 대표적이 다. 그러나 노령인구의 증가와 면역기능 저하 환자의 증가, 장기 이식의 발전과 항암제, 방사선 치료 등으로 과거에 비병원성으 로 생각하였던 균종에 의해서도 기회감염및 중증의 균혈증이 생길수 있음이 보고 되었으며[12], 실제로 이러한 세균들은 심 내막염, 인공 심장 판막, 관절 감염, 호중구 감소증 등과 같은 특 정 임상 조건의 맥락에서 병원성 일 수 있음을 기억해야한다 [13]. 국내의 한 연구에서도 혈액배양 오염균의 가능성이 높은 피부상재균으로 분류되는 Coagulase-negative Staphylococcus (CoNS), Bacillusspp., Corynebacteriumspp., Enterococcus spp., Micrococcus spp., Propionibacterium spp.이 혈액배 양에서 동정되면 임상적인 의미의 해석 없이 모두 분석에 포함 하여 연구하였다는 $\mathrm{GPB}$ 의 분리 동정에 대한 제한점에 대해 보 고한 바 있다[14]. 이러한 제한점이 있음에도 불구하고 임상검 사실에서는 확실한 오염이라고 판단되지 않는 한 일단 양성 세 균의 분리 결과를 보고하고, 그 결과에 대해서는 임상의의 판단 에 맡기는 경우가 많다. 국내외 많은 연구에서는 $\mathrm{GPB}$ 을 포함한 혈액배양에서 분리되는 미생물들에 대해서 균혈증과 관련된 높 은 이환율과 사망률 때문에 신속한 평가와 적절한 경험적 항생

Table 3. Comparison of identification results between MALDI-TOF and 16S-rRNA sequencing of two or more isolates from one patient

\begin{tabular}{|c|c|c|c|}
\hline \multirow{2}{*}{$\begin{array}{l}\text { ID result by } \\
\text { Species }\end{array}$} & \multicolumn{2}{|c|}{ No. of concordant and discordant by MALDI-TOF } & \multirow{2}{*}{$\begin{array}{l}\text { Fianl ID result by } \\
\text { 16S-rRNA sequencing }\end{array}$} \\
\hline & Concordant result & Discordant result & \\
\hline Corynebacterium striatum & 19 & 0 & \\
\hline Bacillus cereus & 5 & 1 & Lysinbacillus sp. \\
\hline Clostridium perfringens & 5 & 0 & \\
\hline Listeria monocytogenes & 9 & 0 & \\
\hline Bacillus iodinum & 1 & 0 & \\
\hline Clostridium carnis & 1 & 0 & \\
\hline Corynebacterium urealyticum & 1 & 0 & \\
\hline Microbacterium species & 0 & 1 & Mycobacterium paraoxydans \\
\hline Mycobacterium abscessus & 1 & 0 & \\
\hline Paenibacillus urinalis & 1 & 0 & \\
\hline Not reliable identification & 0 & 4 & $\begin{array}{c}\text { Cellulomonas hominis } \\
\text { Corynebacterium amycolatum } \\
\text { Catabacter hongkongenesis } \\
\text { Bacillus sp. }\end{array}$ \\
\hline No peaks found & 0 & 1 & Bacillus velezensis \\
\hline Total & 43 & 7 & \\
\hline
\end{tabular}

Abbreviation: No, number. 
제 치료가 매우 중요하다고 강조하고 있다[15]. 혈액배양에서 세균 검출을 위한 분자 진단 기술이 보다 쉽게 이용 가능하고 구 현하기가 용이해질 때까지 임상의는 경험적 치료 결정을 내리 는 데 필요한 예비 자료로 그람 염색법을 계속 의존해야 한다 [16]. 실제적으로 MALDI-TOF MS 기술이 도입되기 전까지는 혈액배양에서뿐만 아니라 임상 검체에서도 $\mathrm{GPB}$ 의 분리율이 낮 을 뿐만 아니라 분리되는 종(species)의 수도 극히 제한되는 경 우가 많았다[17]. 하지만 상대적으로 오염균으로 간주되어지던 $\mathrm{GPB}$ 에 대한 국내 연구는 많은 부족함을 느껴 본 연구를 통해 $\mathrm{GPB}$ 의 분리율과 분리되는 종의 다양성에 대해 알아보았다.

본 연구에서는 일개 대학병원에서 2년간 의뢰된 총 87,241 건 중 양성은 8,699건으로 전체 양성율은 9.97\%였으며, 양성 세균 중 Gram positive cocci는 4,198건(48.3\%), Gram negative bacilli 3,245건(37.3\%), GPB 713건(8.2\%), Candida species는 513건(5.9\%), Gram negative cocci 30건(0.3\%) 순 으로 분리되었다. 이는 $\mathrm{Ahn}$ 등[12]이 보고한, 2002년부터 2006 년까지 혈액배양 양성율은 $18.5 \%$ 로 본 연구에서의 $9.97 \%$ 보다 2배 가량 높은 비율의 양성율을 나타냈으며, Gram positive cocci의 분리율은 $35.1 \%$ 로 본 연구에서 $48.3 \%$ 보다 낮게 나타났고, Gram negative bacilli는 23.9\%로 본 연구에서 의 $37.3 \%$ 로 본 연구보다 낮은 양상을 나타내었으며, $\mathrm{GPB}$ 의 분 리율은 $5.2 \%$ 를 나타내 본 연구에서의 $8.2 \%$ 보다는 낮은 분리율 을 나타냈다. GPB의 5.2\% 중 Bacillus spp. 0.8\%, Erysiphelothrix spp. $0.2 \%$, 기타 $\mathrm{GPB}$ 의 분리율은 $12.8 \%$ 로 보고하였 으며, Candida species는 2.8\%, Gram negative cocci 0.0\%로 본 연구에서의 $0.3 \%$ 와 약간의 차이가 있음을 보고하였다. 국내 다른 연구에서 1998년부터 2010년까지 13년간의 보고에 서는 [14] 전체 양성률에 대한 보고는 없었으나 Gram positive cocci의 분리율은 $50.1 \%$ 로 본 연구에서 $48.3 \%$, Gram negative bacilli는 $38.4 \%$ 로 본 연구에서의 $37.3 \%$ 로 본 연구에 서 와 비슷한 양상을 나타내었으며, $\mathrm{GPB}$ 는 무산소성 막대균을 포함하여 $7.7 \%$ 를 나타내 본 연구에서의 $8.2 \%$ 보다는 약간 낮은 분리율을 나타냈다. Yeasts는 2.8\%로 본 연구에서 $5.9 \%$ 보다 낮 게 나타났다. 결론적으로 2년간 총 혈액배양 양성률은 평균 9.97\%였으며 microflex MALDI Biotyper를 이용하여 총 713 건의 $\mathrm{GPB}$ 을 기기 제조회사의 기준에 따라 균속 동정이 가능한 스코어 1.7 이상 균주는 410 주 $57.5 \%$ 이었다. 동정은 되었으나 스코어 1.7 아래로 신뢰할 수 없는 결과를 보였던 균주는 213 주 로 29.9\%였으며 no peaks found로 동정조차 힘들었던 균주는 90 주 $12.6 \%$ 이었다. 혈액배양 양성세균 중 $\mathrm{GPB}$ 의 양성률은 평 균 $8.2 \%$ 였다. 분기별 분리율은 2015년 3분기는 $9.8 \%, 2016$ 년
2 분기는 $8.7 \%, 2016$ 년 3분기는 $8.1 \%, 2014$ 년 4분기는 $8.1 \%$, 2015 년 1분기는 7.9\%, 2015년 2분기는 7.9\%, 2016년 1분기 는 $6.8 \%, 2015$ 년 4분기는 $6.7 \%$ 순으로 분리되었으며, 분기별 분리률의 차이는 유의성이 없는 것으로 나타났다. 분리 균종별 로는 Corynebacterium striatum 89주 $12.4 \%$, Bacillus cereus 60주 $8.4 \%$, Bacillus subtilis 30주 4.2\%, Paenibacillus urinalis 29 주 $4.1 \%$, Listeria monocytogenes 25 주 3.5\% 순으 로 분리되었다. Listeria spp. 등과 같은 임상적으로도 의의가 많은 감염균의 동정은 다른 연구에서와 비슷한 비율을 나타내 었다[18-20]. 또한 분리 건수는 적지만 Mycobacterium spp., 각종 Corynebacterium spp., Bacillus spp., Clostridium spp.은 1.7 이상에서 신뢰할 수 있을 만한 스코어로 동정할 수 있었다.

물론 동정해내지 못하거나 신뢰할 수 없는 결과도 $42.5 \%$ 로 절반 정도를 차지하였다. 여러 개의 혈액배양병에서 1 개에서만 양성으로 분리된 것은 거의 대부분이 오염균으로 간주되어 감 염균으로의 의의가 없는 것이었다. 그러나 1 개만 분리되었어도 감염의 의의가 있는 Listeria monocytogenes는 25주가 분리 되었다. 최근 우리나라에 공급되기 시작한 MALDI-TOF MS 기 술은 임상미생물검사실에서 세균과 진균을 동정함에 있어 효과 적인 방법으로 인식되고 있고, 사용 또한 늘어나고 있다. 많은 논문에서 임상적으로 의의가 있는 그람양성 알균과 그람음성 막대균, 진균의 대부분이 MALDI-TOF MS를 통해 속수준까지 간편하고 신속하게 동정 가능하다는 것을 보고했다[21].

본 연구에서는 2 년간의 혈액배양에서 분리된 $\mathrm{GPB}$ 의 절반 이 상을 1.7 이상의 스코어에서 신뢰할 수 있을 만한 종(species) 수준까지 다양한 균종의 동정이 가능하다는 것을 확인하였다. 우리의 경험에 의하면 임상미생물검사실에서 분리된 $\mathrm{GPB}$ 을 MALDI-TOF MS 기술을 사용하여 1차 동정해 보고 의의가 있 는 균주에 대해서는 이를 확인하는 전통적 방법이나 $16 \mathrm{~S}-\mathrm{rRNA}$ sequencing 방법을 적용하여 판독한다면 향후 감염균으로서 의의가 있는 $\mathrm{GPB}$ 의 동정에 매우 유용하리라 판단된다.

제한점으로는 흔히 분리되지 않고 비병원성 오염세균이 많 이 포함될 수 있는 $\mathrm{GPB}$ 의 특성으로 인하여 데이터베이스가 부 족하고, 협막이 있는 일부 $\mathrm{GPB}$ 의 구조적 특성상 단백질 분리의 어려움이 있어 동정해 내지 못하는 제한점이 있다. 앞으로 데이 터베이스를 더 확충하고, 단백질 분리가 어려운 $\mathrm{GPB}$ 의 경우 다 른 분리 방법을 추가하여 동정한다면 정확한 동정에 더 많은 도 움이 되리라 생각된다. 


\section{요 약}

본 연구에서는 일개 대학병원에서 2년간 분리된 혈액배양 양 성배지에서 MALDI-TOF MS system을 이용하여 Grampositive bacilli를 동정한 결과를 균종별, 분기별로 분석하였 다. Corynebacterium striatum은 총 89균주 중 66균주 (74.2\%), Bacillus cereus는 60균주 중 44 균주 (73.3\%), Listeria monocytogenes는 25균주 중 25균주 (100\%)로 2.0 이상의 높은 스코어에서 동정되었다. 미 동정 된 균주는 303 균 주 중 293균주는 혈액배양에서 1회 분리 균주로 감염균으로서 의 의의가 없는 오염 균주로 간주되었다. 감염균으로서 의의가 있는 동일 환자 2회 이상 분리 균주 대상 16S-rRNA sequencing 비교결과 총 50 균주 중 43 균주가 일치해 $86.0 \%$ 동정이 가능하 였다. 일치하지 않은 7균주 중 5균주는 MALDI-TOF MS로도 동 정이 되지 않았다.

결론적으로 혈액배양에서 Gram-positive bacilli가 동정되 는 경우, 일차적으로 MALDI-TOF MS를 이용하여 동정해보고 이를 활용한다면 어렵고 비용이 많이 들던 Gram-positive bacilli 동정이 저비용으로 더욱 간편하고 정확해지며, Grampositive bacilli에 의한 감염 진단에도 도움이 될 것으로 판단된다.

\section{Acknowledgements: None}

Conflict of interest: None

Author's information (Position): Choi JU ${ }^{1}$, M.T.; Yu YB ${ }^{2}$, Professor; Kim SH${ }^{3}$, M.T.; Won $\mathrm{S}^{4}$, Professor; Kim $\mathrm{YK}^{2}$, Professor.

\section{REFERENCES}

1. Funke G, von Graevenitz A, Clarridge J3, Berneard KA. Clinical microbiology of coryneform bacteria. Clin Microbiol Rev. 1997;10:125-159.

2. Adderso EE, Boudreaux JW, Hayden RT. Infections caused by coryneform bacteria in pediatric oncology patients. Pediatr Infect Dis J. 2008;27:136-141. https://doi.org/10.1097/INF.0b013 e31814fab12.

3. Barberi SC, Almuzara M, Join-Lambert O, Ramirez MS, Famiglietti A, Vay C. Comparison of the Bruker MALDI-TOF mass spectrometry system and conventional phenotypic methods for identification of Gram-positive rods. PLoS One. 2014: 9:e106303. https://doi.org/10.1371/journal.pone.0106303.

4. Watson RS, Carcillo JA, Linde-Zwirble WT, Clermont G, Lidicker J, Angus DC. The pidemiology of severe sepsis in children in the united stated. Am J Respir Crit Care Med. 2003; 167:695-701. https://doi.org/10.1164/rccm.200207-682OC.

5. Holland RD, Wilkes JG, Rafii F, Sutherland JB, Persons CC,
Voorhees KJ, et al. Rapid identification of intact whole bacteria based on spectral patterns using matrix-assisted laser desorption/ionization with time-of-flight mass spectrometry. Rapid Commun Mass Spectrom. 1996;10:1227-1237. https:// doi.org/10.1002/(SICI)10970231(19960731)10:10〈1227::AIDRCM659> 3.0.CO;2-6.

6. Seng P, Drancourt M, Gouriet F, La Scola B, Fournier PE, Rolain $\mathrm{JM}$, et al. Ongoing evolution in bacteriologyl routine identification of bacteria by matrix-assisted laser desorption ionization itme-offlight mass spectrometry. Clin Infect Dis. 2009; 49:543-551. https://doi.org/10.1086/600885.

7. Bizzini A, Durussel C, Bille J, Greub G, Prod'hom G. Performance of matrix-assisted laser desorption ionizationtime of flight mass spectrometry for identification of bacterial strains routinely isolated in a clinical microbiology laboratory. J Clin Microbiol. 2010;48: 1549-1554. https://doi.org/10.1128/ JCM.01794-09.

8. Stevenson LG, Drake SK, Shea YR, Zelazny AM, Murray PR. Evaluation of matrix-assisted laser desorption ionization-time of Flight mass spectrometry for identification of clinically important yeast species. J Clin Microbiol. 2010;48:3482-3486. https://doi.org/10.1128/JCM.00687-09.

9. Park KG, Yu YB, Yook KD, Kim SH, Kim SH, Kim YG. An evaluation of the rapid antimicro bial susceptibility test by VITEK MS and VITEK 2 Systems in blood culture. Korean J Clin Lab Sci. 2017;49:279-284. https://doi.org/10.15324/kjcls.

10. Carbonnelle E, Grohs P, Jacquier H, Day N, Tenza S, Dewailly A, et al. Robustness of two MALDI-TOF mass spectrometry systems for bacterial identification. J Microbiol Methods. 2012;89:133-136. https://di.org/10.1016/j.mimet.2012.03.003.

11. Dubois D, Grare M, Prere MF, Segonds C, Marty N, Oswald E. Performances of the Vitek MS matrix-assisted laser desorption ionization-time of flight mass spectrometry system for rapid identification of bacteria in routine clinical microbiology. J Clin Microbiol. 2012;50:2568-2576. https://doi.org/10.1128/ JCM. 00343-12.

12. Ahn GY, Jang SJ, Lee SH, Jeong OY, Bidur Prasad Chaulagain BP, Moon DS, et al. Trends of the species and antimicrobial susceptibility of microorganisms isolated from blood cultures of patients. Korean J Clin Microbiol. 2006;9:42-50.

13. Navas M, Pincus DH, Wilkey K, LaSalvia M, Wilson D, Procop GW, et al. Identification of aerobic Gram-positive bacilli by use of Vitek MS. J Clin Microbiol. 2014;52:1274-1277. https://doi.org/10.1128/JCM.03483- 13 .

14. Kim NH, Hwang JH, Song KH, Choe PG, Park WB, Kim ES, et al. Changes in antimicrobial susceptibility of blood isolates in a university hospital in South Korea, 1998-2010. Infect Chemother. 2012;44:275-281. https://doi.org/10.3947/ic.2012. 44.4.275.

15. Woo PC, Lau SK, Teng JL, Tse H, Yuen KY. Then and now: use of 16S rDNA gene sequencing for bacterial identification and discovery of novel bacteria in clinical microbiology laboratories. Clin Microbiol Infect. 2008;14:908-934. https://doi.org/ 10.1111/j.1469-0691.2008.02070.x.

16. Bruins MJ, Bloembergen P, Ruijs GJ, Wolfhagen MJ. Identification and susceptibility testing of enterobacteriaceae and pseudomonas aeruginosa by direct inoculation from pos- 
itive BACTEC blood culture bottles into VITEK 2. J Clin Microbiol. 2004;42:7-11. https://doi.org/10.1128/JCM.42.1.711.2004.

17. Shin KS, Son YI, Kim TD, Hong SB, Park JS, Kim SH, et al. Secular trends of species and antimicrobial resistance of blood isolates in a tertiary medical center for ten years: 2003 2012. Biomedical Science Letters. 2014;20:2288-7415.

18. Choi SK, Han MH, Bae CW, Choi YS. A case of paenibacillus-induced sepsis complicated with pneumotocele in a very low birth weight infant. Neonatal Med. 2014;21:69-73. https://doi.org/10.5385/nm.2014.21.1.69.

19. Renom F, Gomila M, Garau M, Gallegos M.D.C, Guerrero D, Lalucat J, et al. Respira tory infection by Corynebacterium stria- tum: epidemiological and clinical determinants. New Micorbes New Infect. 2014;2:106-114. https://doi.org/10.1002/nmi2.48. 20. Severo CB, Guazzelli LS, Barra MB, Hochhegger B, Severo LC. Multiple pulmonary nodules caused by Corynebacterium striatum in an immunocompetent patient. Rev Inst Med Trop Sao Paulo. 2014;56:89-91. https://doi.org/10.1590/S0036-466520 14000100015 .

21. Levesque S, Dufresne PJ, Soualhine H, Doming M-C, Bekal S, Lefebvre B, et al. A side by side compariton of Bruker Biotyper and VITEK MS Utility of MALDI-TOF MS technolo gy for microorganism identification in a public health reference laboratory. PLOS ONE. 2015;10:e0144878. https://doi.org/10.1371/journal. pone.0144878. 